\title{
Vicarious Liability in Groups of Companies and in Supply Chains - Is Competition Law Leading the Way?*
}

Vibe Ulfbeck*

ABSTRACT: The article discusses the concept of vicarious liability in the area of competition law. It argues that this concept is to some extent embedded in the concept of the undertaking under competition law with the consequence that parent companies - under certain conditions - can be held liable for competition law infringements committed by subsidiaries. The liability can be termed "vicarious" because it is imposed regardless of whether the parent company was involved in or ought to have had any knowledge of the competition law infringements committed by the subsidiary. Whereas such liability has until recently only been imposed for administrative fines, the Skanska decision changes this. Following this decision it must be assumed that parent companies can also be held vicariously liable for civil liability incurred by a subsidiary. It is pointed out that it is a separate question whether the Akzo-presumption rule, established with regard to the imposition of fines for competition law infringements, can also be applied in a pure civil liability case concerning parental liability. Next, the article discusses whether the results reached in the area of competition law can be transferred to other areas of the law. In this regard, the article analyses recent case law with regard to parental liability for workers' injuries and environmental damage and compares these areas of the law to competition law. Finally, the article discusses whether the concept of the undertaking can be extended to apply also in situations where companies are not tied by ownership but by contract. In this regard the article focuses on the (possibly) emerging concept of supply chain liability.

\footnotetext{
* Date of reception: 1 July 2019. Date of acceptance: 17 August 2019.

DOI: https://doi.org/10.7559/mclawreview.2019.2361.

** University of Copenhagen, Faculty of Law, CEVIA (Centre for Enterprise Liability). 2300 Copenhagen, Denmark. Vibe.Ulfbeck@jur.ku.dk. The article is a contribution to the Project Private/Public Enterprise Liability, funded by the Danish Council for Independent Research (FSE). I would like to thank Professor Georgio Monti, University of Tilburg for comments on an earlier version of this article. Responsibility is with the author.
} 
KEYWORDS: Competition Law, Vicarious Liability, Groups of Companies, Supply Chains, Private Enforcement

\section{Introduction}

In competition law, it has been established since long that a parent company and a subsidiary may be regarded under certain conditions as a "single economic unit" - an "undertaking" - with the consequence that the parent company can be held liable if the subsidiary has incurred administrative liability (through imposition of fines) for competition law infringements. Although this parental liability has been much criticised, it must be assumed that with the Skanska decision, the liability of the parent company for the acts and omissions of the subsidiary ("vicarious liability") has been widened. The question of parental liability for competition law infringements is part of a wider question of the possible liability of companies for acts and omissions of other companies with which they are somehow linked. This article firstly describes the development of the concept of the undertaking in the area of competition law and examines the implications of the Skanska decision for groups of companies with regard to competition law infringements (section 2). Secondly, it asks whether a similar pattern of development can be found in other areas of the law and whether the solutions adopted in competition law can be transferred to these other areas (section 3) and thirdly, whether the concept of an undertaking could be applicable not only to companies linked by ownership but also to companies linked by contract (section 4).

\section{Liability for competition law infringements in groups of companies}

\subsection{Criminal law liability}

\subsubsection{Phase 1: The concept of the undertaking as a shield}

The question of parental liability for competition law infringements hinges on the concept of "undertaking" as developed and explained in CJEU case law.

As it has been pointed out in legal literature, ${ }^{1}$ originally the concept of "undertaking" was developed as a tool for companies connected in a group

\footnotetext{
${ }^{1}$ Bernardo Cortese, "Piercing the corporate veil in EU Competition Law: The parent subsidiary relationship and antitrust liability", in EU Competition Law - Between Public and Private Enforcement, ed. Bernardo Cortese (Alphen aan den Rijn: Kluwer Law International, 2014), 73-74.
} 
to avoid being subject to the EC competition law rules. Thus, the purpose was to exclude "intra-group" agreements from article 85 EEC. This was expressed in the Beguelin decision from the beginning of the 70s' where article 85 was found inapplicable when a subsidiary "although having a separate legal personality, enjoys no economic independence". ${ }^{2}$ In this case, the concept of economic unit could be said to be used as a "shield" and this application of the concept of undertaking could be seen as representing a first phase in its development. ${ }^{4}$

\subsubsection{Phase 2: Direct liability}

Soon afterwards, however, the concept of economic unit was also used as a "sword". In a number of cases, the concept was merely used for establishing the jurisdiction of the Commission over parent companies established in non-Member States. For instance, this was the case in the Imperial Chemical Industries ruling, ${ }^{6}$ where the court stated that it would not be possible to exclude the possibility of imputing the conduct of the subsidiary to the parent company when "the subsidiary, although having separate legal personality, does not decide independently upon its own conduct on the market, but carries out, in all material respects, the instructions given by the parent company". ${ }^{7}$ Based on this observation, the court found that the parent company and the subsidiary rightly were to be regarded as one economic unit and consequently, the Commission also had jurisdiction over the foreign parent company. ${ }^{8}$ With regard to the liability assessment however, the concept of the economic unit was not relevant, since there was proof that the parent company had directly ordered the subsidiary to

\footnotetext{
${ }^{2}$ Judgment of 25 November 1971, Beguelin Import v. S.A.G.L. Import Export, C- 22/71, EU:C:1971:113, paragraph 8.

${ }^{3}$ Cortese, "Piercing", 74.

${ }^{4}$ The case was followed up by a series of cases applying the same line of reasoning. For an overview, see Cortese, "Piercing", 75-76.

${ }^{5}$ For an overview of cases taking this approach, see Cortese, "Piercing", 76-78.

${ }^{6}$ Judgment of 14 July 1972, Imperial Chemical Industries Ltd v. Commission of the European Communities, C-48/69, ECLI:EU:C:1972:70.

${ }^{7}$ Judgment of 14 July 1972, Imperial Chemical Industries Ltd v. Commission of the European Communities, C-48/69, ECLI:EU:C:1972:70, paragraph 133.

${ }^{8}$ Judgment of 14 July 1972, Imperial Chemical Industries Ltd v. Commission of the European Communities, C-48/69, ECLI:EU:C:1972:70, paragraphs 139-142.
} 
establish illegal cartels. ${ }^{9}$ In other words, the liability of the parent company was direct (as opposed to vicarious).

In a series of subsequent cases, ${ }^{10}$ where procedural issues were not at stake, the court upheld the view that even in case of wholly owned subsidiaries it was necessary for the Commission to establish that the parent company had in fact exercised influence on the subsidiary and that there was a connection between this control and the infringements committed by the subsidiary. ${ }^{11}$ In other words, liability in this phase of the development was direct, fault-based liability. ${ }^{12}$

\subsubsection{Phase 3: Vicarious liability}

However, a marked shift in the approach occurred with the Akzo Nobel decision, ${ }^{13}$ which concerned a wholly owned subsidiary that had engaged in an illegal cartel. In its decision, the court established two things. Firstly, regardless of fault, a parent company which exercises a sufficient amount of control with its subsidiary can be held liable for the administrative fines imposed on its subsidiary on the basis that the two legal entities constitute an economic unit. ${ }^{14}$ It is not a requirement that the parent company has been involved in the infringement or that there is a connection between the control exercised by the parent and the infringement committed by the subsidiary. It is not even a requirement that the parent company knew or ought to have known of the infringements committed by the subsidiary. Rather, the knowledge of the subsidiary is automatically imputed to the parent company once it is established that the parent company and

\footnotetext{
${ }^{9}$ Judgment of 14 July 1972, Imperial Chemical Industries Ltd v. Commission of the European Communities, C-48/69, ECLI:EU:C:1972:70, paragraph 138.

${ }^{10}$ See, for instance, Judgment of 2 October 2003, Madrid SL v. Commission, C-196/99, EU:C:2003:529, Judgment of 28 June 2005, Dansk Rørindustri and others v. Commission, joined cases C-189/02 P, C-202/02 P, C-205/02 P, C-208/02 P, C-2013/02 P, ECLI:EU:C:2005:408.

${ }^{11}$ Andriani Kalintiri, "Revisiting parental liability in EU competition law", European Law Review 43, no. 2 (2018): 4-5, http://eprints.lse.ac.uk/87251/1/Kalintiri_\%20Revisiting\%20parental\%20 liability_2018_author.pdf, pointing out that the existence of the economic unit at this time was a necessary, but not a sufficient condition and that for liability to arise, the parent company should be shown to have itself contributed to the infringement. See also Cortese, "Piercing", 84.

${ }^{12}$ Cortese, "Piercing", 77.

${ }^{13}$ Judgment of 10 September 2009, Akzo Nobel NV v. Commission of the European Communities, C-97/08P, EU:C:2009:536. On the decision Judgment of 16 November 2000, Stora Kopparbergs Bergslags AB v. Commission of the European Communities, C-286/98 P, EU:C:2000:630, as paving the way for the Akzo Nobel decision, see Kalintiri, "Revisiting", 5.

${ }^{14}$ Judgment of 10 September 2009, Akzo Nobel NV v. Commission of the European Communities, C-97/08P, EU:C:2009:536, paragraphs 58-59.
} 
the subsidiary form an economic unit. Secondly, when a parent is the sole owner of a subsidiary there is a presumption that the parent company exercises decisive influence over the conduct of the subsidiary and that the parent company and the subsidiary therefore constitute an undertaking (the Akzo Nobel presumption rule). ${ }^{15}$ The presumption can be rebutted if the parent company can show that the subsidiary acts independently on the market. ${ }^{16}$ In other words, unless the parent company can show that the subsidiary acts independently on the market, the parent and the subsidiary are considered to form an undertaking for the purpose of competition law rules and the parent company will be held liable for the competition law infringements committed by the subsidiary. ${ }^{17}$ Thus, the presumption rule puts the burden of proof regarding lack of control on the parent company. In practice, it is extremely difficult for a parent company to rebut the presumption of control.

The general liability rationale behind the Akzo Nobel-ruling has been explained in the following way:

"Given that parent companies, as shareholders, benefit from their subsidiaries' antitrust infringements, not holding parent companies liable would create a perverse incentive for parent companies to encourage their subsidiaries to engage in antitrust infringements, in particular by setting excessive financial targets or incentives that create pressure to commit infringements". ${ }^{18}$

The Akzo Nobel presumption rule has been criticised for sitting uneasily with human rights principles, such as the principle of the presumption of innocence, the principle of legal certainty, the principle of the right of the accused to a defence ${ }^{19}$ and the principle that penalties should be applied solely to the offender. Regardless of this, the Akzo Nobel presumption has been upheld by the court.

\footnotetext{
${ }^{15}$ Judgment of 10 September 2009, Akzo Nobel NV v. Commission of the European Communities, C-97/08P, EU:C:2009:536, paragraphs 60-61.

${ }^{16}$ Judgment of 10 September 2009, Akzo Nobel NV v. Commission of the European Communities, C-97/08P, EU:C:2009:536,paragraph 61.

${ }^{17}$ Judgment of 10 September 2009, Akzo Nobel NV v. Commission of the European Communities, C-97/08P, EU:C:2009:536, paragraph 61.

${ }^{18}$ Wouter P. J. Wils, "Antitrust compliance programmes and optimal antitrust enforcement", Journal of Antitrust Enforcement 1, no. 1 (2013): 52-81, 60.

${ }^{19}$ On this see inter alia Marco Bronckers, Anne Vallery, "No longer presumed guilty? The impact of fundamental rights on certain dogmas of EU Competition Law", World Competition 34, no. 4 (2011): 535-570. See also A. Menarini Diagnostics SRL v. Italy, Application no. 43509/08.
} 
Aside from the presumption rule, also the very basic system of imputing responsibility to the parent company for the acts and omissions of the subsidiary has been criticised for introducing an unclear system of vicarious liability. ${ }^{20}$ However, in the Elf Aquitaine case, the CJEU stated that the court has not established "a system of liability for the acts of others", ${ }^{21}$ rather the parent company is held liable because it cannot be distinguished from the subsidiary. The view that the court has not established a system of liability for the acts of others can be contested. ${ }^{22}$ In reality, liability is imposed on an entity with legal personality on the basis that another entity with a separate legal personality has infringed competition law rules. Since there is no requirement that the parent company was involved or had knowledge or ought to have had knowledge of the infringements committed by the subsidiary, the created liability standard can in tort law terms most naturally be described as vicarious liability (liability for others). However, the Akzo Nobel-ruling makes clear that this kind of liability can only be imposed if two companies are so "integrated" that they cannot in reality be distinguished from one another. ${ }^{23}$

The Akzo Nobel case concerned a wholly owned subsidiary. However, also in cases of partial ownership it is possible to reach the conclusion that the parent company and the subsidiary should be regarded as one entity. The closer the shareholding in the subsidiary is to $100 \%$, the easier it is to arrive at this result, and in cases where ownership is close to $100 \%$, the Akzo Nobel presumption will apply. ${ }^{24}$

In contrast, outside the scope of the principle of "nearly $100 \%$ ownership", the Akzo Nobel presumption rule does not apply. ${ }^{25}$ In these cases, it is necessary for the plaintiff to establish that the parent company did in fact exercise control over the subsidiary. ${ }^{26}$ In this respect, various criteria apply. For example, the use of the same name or trademark, creating the perception of unity for third parties, can be an argument that the companies

\footnotetext{
${ }^{20}$ Judgment of 1 October 2013, Elf Aquitaine SA v. European Commission, C-521/09 P, EU:C:2011:620, paragraph 85.

${ }^{21}$ Judgment of 1 October 2013, Elf Aquitaine SA v. European Commission, C-521/09 P, EU:C:2011:620, paragraph 85, paragraphs 87, 88.

${ }^{22}$ See also Cortese,"Piercing", 87.

${ }^{23}$ Judgment of 10 September 2009, Akzo Nobel NV v. Commission of the European Communities, C-97/08P, EU:C:2009:536, paragraphs 58-59.

${ }^{24}$ Kalintiri, "Revisiting”, 8, with references to case law.

${ }^{25}$ Kalintiri, "Revisiting”, 9.

${ }^{26}$ Kalintiri, "Revisiting”, 9, with reference to case law.
} 
should be regarded as an economic unit. ${ }^{27}$ Also overlapping positions on boards of directors and in supervisory bodies may be relevant to take into account when evaluating whether a parent company and a subsidiary should rightly be considered one economic entity. ${ }^{28}$ Likewise, the direct or indirect use of parents' assets (including managers) by the subsidiary may be relevant ${ }^{29}$, as may instructions to the subsidiary or reporting lines going from the subsidiary to the parent. ${ }^{30}$ Finally, accounting practices, and the extent to which sales from a subsidiary to a parent company appear in the papers as intra-group, may also be used as criteria. ${ }^{31}$

Joint venture liability cases show that even in cases of $50 \%$ ownership and less, it may be possible to establish a sufficient amount of influence on the part of the parent company to reach the conclusion that the parent companies and subsidiaries form an economic unit. This was made clear in the case Dow, ${ }^{32}$ concerning joint venture and 50\% ownership of each parent company, where the court listed a number of criteria relevant to the understanding of the concept of an "undertaking" related to joint ventures. In this regard, the court found it relevant that the parent companies had management power over the subsidiaries through a joint members committee, ${ }^{33}$ so that the parent companies could carry out supervision of the subsidiary ${ }^{34}$ and its compliance with the policies of the parent company. ${ }^{35}$ In the joint venture case Toshiba, the court even acknowledged that

\footnotetext{
${ }^{27}$ Judgment of 1 July 2010, Knauf Gips KG v. European Commission, C-407/08P, EU:C:2010:389, paragraph 104 .

${ }^{28}$ Judgment of 16 November 2000, Stora Kopparbergs Bergslags AB v. Commission of the European Communities, C-286/98 P, EU:C:2000:630, paragraph 6.

${ }^{29}$ Judgment of 1 July 2010, Knauf Gips KG v. European Commission, C-407/08P, EU:C:2010:389, paragraph 67.

${ }^{30}$ E. Islentyeva "Like father, like son - The parental liability under the EU Competition Law today", Global Antitrust Review (2011): 99, 111.

${ }^{31}$ Judgment of 16 November 2000, Stora Kopparbergs Bergslags AB v. Commission of the European Communities, C-286/98 P, EU:C:2000:630, paragraph 9.

${ }^{32}$ Judgment of 2 February 2012, Dow Chemical v. European Commission, T-77/08, EU:T:2012:47. See also Judgment of 2 February 2012, El Du Pont de Nemours and Others v. European Commission, T-76/08, EU:T:2012:46; Judgment of 26 September 2013, El Du Pont de Nemours and Others v. European Commission, C-172/12 P, EU:C:2013:601.

${ }^{33}$ Judgment of 2 February 2012, Dow Chemical v. European Commission, T-77/08, EU:T:2012:47, paragraph 87.

${ }^{34}$ Judgment of 2 February 2012, Dow Chemical v. European Commission, T-77/08, EU:T:2012:47, paragraph 101.

${ }^{35}$ Judgment of 2 February 2012, Dow Chemical v. European Commission, T-77/08, EU:T:2012:47, paragraph 101.
} 
a share of $35.5 \%$ in combination with other criteria could be sufficient to establish influence on the part of the parent company to such an extent that liability could be imputed. ${ }^{36}$ On this basis, one might ask whether it would be possible to reach the conclusion that two companies could form an undertaking even in the absence of any ownership if they are in other ways tightly connected. ${ }^{37}$

The criteria listed show that, unlike in the cases mentioned above under phase 2, it is no longer a requirement to establish control on the part of the parent company with the particular acts that constitute competition law infringements by the subsidiary. As under the Akzo Nobel-ruling rule, control may be exercised at a more general level. Also, as under the Akzo Nobel-ruling, it is not a requirement that the parent company had actual knowledge of the competition law infringements in order for it to be held liable for the acts of the subsidiary. The reason for this is that the knowledge of the subsidiary is automatically imputed to the parent company when the two companies are considered one undertaking. Consequently, from a tort law perspective, the liability concept, also outside the area of the applicability of the Akzo Nobel presumption rule, seems to be best described as vicarious liability as long as liability builds on the concept of an undertaking, tying together the parent company and the subsidiary. ${ }^{38}$ From a tort law perspective, the fact that vicarious liability is embedded in the concept of the undertaking makes this concept particularly interesting. Thus, in tort law, it is the general rule that a tortfeasor can only be held liable for its own acts and only in exceptional circumstances for the acts of others. ${ }^{39}$

\subsection{The Skanska decision}

Prior to the Skanska decision, ${ }^{40}$ it was uncertain whether the doctrine of the economic unit, as developed with regard to administrative liability, would also apply to civil liability incurred by the subsidiary. In European

\footnotetext{
${ }^{36}$ Judgment of 9 September 2015, Toshiba v. European Commission, T-104/13, C-623/15, EU:T:2015:610; Kalintiri, "Revisiting”, 9.

${ }^{37}$ On this, see further below under 4.

${ }^{38}$ On the categorisation of the liability as 'vicarious', see above under 2.1.3.

${ }^{39}$ See Suzanne Galand-Carval, "Comparative report for damage caused by others", in Unification of Tort Law: Liability for Damage Caused by Others, ed. Jaap Spier (Alphen aan den Rijn: Kluwer Law International, 2003), 306.

${ }^{40}$ Judgment of 14 March 2019, Vantaan Kaupunki v. Skanska Industrial Solutions Oy, NCC Industry Oy, Asfaltmix Oy, C-724/17, EU:C:2019:204.
} 
jurisdictions, cases have been going in different directions, ${ }^{41}$ and in legal literature opinions have differed. ${ }^{42}$ On the one hand, it could be argued that it must be less controversial to apply vicarious liability principles to civil liability than to criminal liability. Thus, the imposition of vicarious liability in civil law cases - although exceptional as a legal principle - can hardly attract human rights concerns. On the other hand, vicarious liability for civil liability may give rise to other concerns with regard to EU law (see further below).

The introduction of the damages directive, ${ }^{43}$ making (entirely) clear that private actors may sue for competition law infringements under tort law, accelerated the need to clarify the issue. Thus, the directive makes use of the concept of "undertaking" in defining the infringer under the directive, ${ }^{44}$ but does not define the concept of undertaking. This further emphasised the relevance of the question whether the concept of undertaking as defined by the CJEU and applied with regard to criminal liability can be transferred to the area of civil liability.

The Skanska decision, which was decided according to the law as it stood before the entering into force of the directive, concerned a cartel in the asphalt market set up in Finland. The question before the court was whether a company that had acquired another company could be held liable in a civil law case for competition law infringements committed by the acquired company, which had now gone bankrupt (i.e. a case of succession/continuity)..$^{45}$ The Finnish state argued that this would be contrary to Finnish national company law, which adheres to the doctrine of separate entities and only recognises deviation from this principle in exceptional cases, for instance if a structure of separate entities has deliberately

\footnotetext{
${ }^{41}$ In the UK, the Provini case [2013] EWHC 961 relies on the principle of the economic unit and imposes civil liability on the parent company for competition law infringements of the subsidiary, whereas a French decision, Cour de Cassation Chambre Commerciale, 15 Novembre 2011, Societé JC Bramford Escavators ltd., Societé JCB Finance ltd., Societé JCB Sales ltd., Societé JCB Services contre Societé Central Parts, case no. 10-21.701, rejects the application of the principle with regard to civil liability.

${ }^{42}$ Critical Cortese, "Piercing", 92.

${ }^{43}$ Directive 2014/104/EU of 26 November 2014 on certain rules governing actions for damages under national law for infringements of the competition law provisions of the Member States and of the European Union.

${ }^{44}$ Article 1(1).

${ }^{45}$ Judgment of 14 March 2019, Vantaan Kaupunki v. Skanska Industrial Solutions Oy, NCC Industry Oy, Asfaltmix Oy, C-724/17, EU:C:2019:204, paragraph 23.
} 
been used in an attempt to avoid liability. ${ }^{46}$ The company (Asfaltmix) also argued that the doctrine of the economic unit in EU competition law only applied to with regard to administrative liability, not civil liability. ${ }^{47}$ The CJEU rejected these arguments and stated that the concept of the undertaking was applicable not only with regard to administrative liability but also with regard to civil liability. The court stated:

"if the undertakings responsible for damage caused by an infringement of the EU competition rules could escape penalties by simply changing their identity through restructurings, sales or other legal or organisational changes, the objective of suppressing conduct that infringes the competition rules and preventing its reoccurrence by means of deterrent penalties would be jeopardized (...) It follows that the concept of 'undertaking', within the meaning of article 101 TFEU, which constitutes an autonomous concept of EU law, cannot have a different scope with regard to the imposition of fines by the Commission (...) as compared with actions for damages for EU competition rules". ${ }^{4}$

Although the case concerns the liability of a company which has acquired another company (a succession case), it must be assumed that the decision will have implications also for the question of the liability of the parent company for the acts and omission of their subsidiaries. ${ }^{49}$ Thus, the main problem with regard to imposing liability in these cases is the same as in the Skanska decision: Liability can be seen as running counter to the basic company law principle of separate entities. In the Skanska decision, it was explicitly pointed out that Finnish rules on civil liability are based on the principle that only the legal entity that caused the damage is liable and that it is possible to "pierce the corporate veil" only if "the operators

\footnotetext{
${ }^{46}$ Judgment of 14 March 2019, Vantaan Kaupunki v. Skanska Industrial Solutions Oy, NCC Industry Oy, Asfaltmix Oy, C-724/17, EU:C:2019:204, paragraph 15, where it is explained that, with regard to piercing the corporate veil, Finnish law is primarily case-based.

${ }^{47}$ Judgment of 14 March 2019, Vantaan Kaupunki v. Skanska Industrial Solutions Oy, NCC Industry Oy, Asfaltmix Oy, C-724/17, EU:C:2019:204, paragraph 41.

${ }^{48}$ Judgment of 14 March 2019, Vantaan Kaupunki v. Skanska Industrial Solutions Oy, NCC Industry Oy, Asfaltmix Oy, C-724/17, EU:C:2019:204, paragraphs 46 and 47.

${ }^{49}$ In support of this view, see Judgment of 14 March 2019, Vantaan Kaupunki v. Skanska Industrial Solutions Oy, NCC Industry Oy, Asfaltmix Oy, C-724/17, EU:C:2019:204, paragraph 15, where the CJEU equals sales to other structural changes in speaking about the risk of companies escaping penalties through "restructurings, sales or other legal or organizational changes".
} 
concerned used the group structure, the relationship between the companies or the shareholder's control in a reprehensible or artificial manner, resulting in the avoidance of liability" ${ }^{50}$ In other words, it was made clear that under Finnish law the basic company law principle of separate entities would - as a general rule - be regarded as barring the imposition of liability in a case like this. However, the CJEU found that these basic company law principles must yield to the understanding of the concept of "undertaking" under article $101^{51}$. Consequently, it must be assumed that the concept of the undertaking as developed by the court will apply also to parent companies in cases concerning their civil liability for competition law infringements by a subsidiary.

A separate question is whether the Akzo Nobel presumption rule will also apply in civil liability cases concerning wholly owned subsidiaries. Thus, in legal theory it has been argued that an application of the presumption rule in cases concerning civil liability would run counter to the procedural autonomy principle under EU law, according to which matters of procedure are left to national law, unless EU law explicitly imposes a uniform approach. ${ }^{52}$ A presumption rule shifts the burden of proof from the plaintiff to the defendant. It could be argued that this is indeed a procedural rule. However, it could also be argued that the presumption rule should rather be seen as forming part of liability standard on vicarious liability, which has nothing to do with procedural law issues. The Skanska decision does not rule on the question of the applicability of the Akzo Nobel presumption rule in civil liability cases explicitly as it concerns a case of succession and economic continuity rather than parental liability. However, in the Skanska decision, the court emphasised that "actions for damages for infringement of EU competition rules are an integral part of the system for enforcement of those rules" ${ }^{\prime 53}$ and for that reason the concept of the undertaking should be understood in the same way with regard

\footnotetext{
${ }^{50}$ Judgment of 14 March 2019, Vantaan Kaupunki v. Skanska Industrial Solutions Oy, NCC Industry Oy, Asfaltmix Oy, C-724/17, EU:C:2019:204, paragraph 15, where the Finnish rules on civil liability, which are primarily based on case law, are explained.

${ }^{51}$ Judgment of 14 March 2019, Vantaan Kaupunki v. Skanska Industrial Solutions Oy, NCC Industry Oy, Asfaltmix Oy, C-724/17, EU:C:2019:204, paragraph 36.

${ }^{52}$ Cortese, "Piercing", 93.

${ }^{53}$ Judgment of 14 March 2019, Vantaan Kaupunki v. Skanska Industrial Solutions Oy, NCC Industry Oy, Asfaltmix Oy, C-724/17, EU:C:2019:204, paragraph 45.
} 
to administrative and civil liability. ${ }^{54}$ This would seem to suggest that also the Akzo Nobel presumption rule must be regarded as "imported" into the area of parental civil law liability for competition law infringements.

\section{Liability in groups of companies in other areas of the law-lessons to be learned from competition law?}

\subsection{General introduction to other areas}

The possible liability of parent companies for the acts of their subsidiaries has also increasingly attracted interest in areas of the law other than competition law. In particular, this is true with regard to liability for workers' injuries and environmental harm. One of the reasons for this increased interest is a pressure stemming from internationally adopted soft law norms. As examples the UN Global Compact ${ }^{55}$, the UN Guiding Principles ${ }^{56}$, and the OECD principles for multinational enterprises could be mentioned. ${ }^{57}$

The following focuses on recent developments in primarily European law concerning parental liability for work injuries and environmental harm caused by subsidiaries. The focus is primarily on cases with transnational elements (so-called foreign direct liability cases), ${ }^{58}$ although certain national cases will also be included. In contrast to the competition law area, cases have not primarily concerned administrative liability. A number of civil law suits have been brought. Nevertheless, following the Skanska decision, the law seems less developed with regard to parental liability in these areas of the law than in the area of competition law. This is further explained in the following.

\footnotetext{
${ }^{54}$ Judgment of 14 March 2019, Vantaan Kaupunki v. Skanska Industrial Solutions Oy, NCC Industry Oy, Asfaltmix Oy, C-724/17, EU:C:2019:204, paragraph 47.

${ }^{55} \mathrm{UN}$ Global Compact, available at www.unglobalcompact.org.

${ }^{56}$ John Ruggie, "Guiding principles on business and human rights: Implementing the United Nations 'protect, respect and remedy' framework". https://www.ohchr.org/documents/publications/GuidingprinciplesBusinesshr_eN.pdf.

${ }^{57}$ OECD Guidelines for Multinational Enterprises, available at www.oecd.org.

${ }^{58}$ Liesbeth Enneking, Foreign Direct Liability and Beyond. Exploring the Role of Tort Law in Promoting International Corporate Social Responsibility and Accountability (The Hague: Eleven International Publishing, 2012).
} 


\subsection{Developments in case law}

\subsubsection{Direct liability}

Cases concerning the possible parental liability for the acts and omissions of subsidiaries are familiar across different legal systems, and company law in most European legal systems only allow for "piercing of the corporate veil" under certain specific circumstances such as abuse of legal entities in serious cases. ${ }^{59}$ However, cases concerning parental liability for workers' injuries and/or environmental damage need not necessarily be based on company law principles on veil piercing but can be based on basic tort law principles. ${ }^{60}$ Since the basic tort law liability principle is fault, this means that it is necessary to demonstrate some degree of control on the part of the parent company with the subsidiary.

In many European legal systems, $100 \%$ ownership or nearly $100 \%$ ownership combined with proof of some degree of control by direction or coordination of the activities of the subsidiary are requirements for showing the necessary degree of control. ${ }^{61}$ The emphasis on the amount of ownership corresponds with the criteria under competition law. Also other indicators are relevant such as consolidated accounts, identity between boards of parent companies and subsidiaries and codes of conduct regarding CSR matters applying to the entire group of companies. ${ }^{62}$ As in the area of competition law, cases have concerned both situations of active involvement in the shape of "orders" on the part of the parent company to commit torts and situations where the parent company has failed to prevent infliction of harm by the subsidiary of which it had knowledge or ought to have had knowledge. ${ }^{63}$

That liability can also be incurred for omissions was illustrated in the much discussed Chandler case, ${ }^{64}$ where a parent company was held liable for work injuries sustained by employees, exposed to asbestos, in a fully

\footnotetext{
${ }^{59}$ Cees van Dam, “Tort law and human rights: Brothers in arms - On the role of tort law in the area of business and human rights", Journal of European Tort Law 2, no. 3 (2011): 221, 247.

${ }^{60}$ Peter Rott and Vibe Ulfbeck, "Supply chain liability of multinational corporations?", European Review of Private Law 23, no. 3 (2015): 415, 432.

${ }^{61}$ Van Dam, "Brothers in arms": 248, pointing out also that details vary in the different European systems.

${ }^{62}$ Van Dam, "Brothers in arms": 249

${ }^{63}$ Van Dam, "Brothers in arms": 250.

${ }^{64}$ Chandler v. Cape, [2012] EWCA Civ. 525.
} 
owned subsidiary. ${ }^{65}$ The case concerned the omission of the parent company to prevent the injuries and the court found that the parent company had assumed liability towards the workers of the subsidiary, in particular because of the parent company's superior knowledge in the area, its knowledge of the problems at the workplace and knowledge that the workers employed by the subsidiary would have expectations to be protected against such risks by the parent company. It is worth noticing, however, that control in itself is not enough to establish liability under the Chandler ruling. It is also a requirement that the parent company knew or ought to have known that the subsidiary was violating the norms in question. ${ }^{66}$

Moreover, although parental liability cases have typically concerned parent companies with majority shares in the subsidiaries, no presumption rule similar to the Akzo Nobel presumption rule in the area of competition law has been suggested. ${ }^{67}$ This means that with regard to the actual exercise of control in cases concerning workers' injuries and environmental damage, the burden of proof is on the plaintiff. ${ }^{68}$ It also follows that it is necessary for the plaintiff to prove that the parent company had knowledge or ought to have had knowledge of the infringements caused by the subsidiary.

In other words, so far, parental liability in areas of the law other than competition law can probably best be described as being in phase 2 , with the reservation that liability cases concern not only administrative liability, but also civil liability.

\footnotetext{
${ }^{65}$ For a discussion of the case and related ones, see for instance Vibe Ulfbeck and Andreas Ehlers, "Direct and vicarious liability in supply chains", in Law and Responsible Supply Chain Management, eds. Vibe Ulfbeck, Alexandra Andhov, Katerina Mitkidis (Abingdon: Routledge, 2019), 91.

${ }^{66}$ Chandler v. Cape, [2012] EWCA Civ. 525, paragraph 80.

${ }^{67}$ Although the competition law concept of the undertaking is often mentioned in literature concerning parental liability in other areas of the law, the application of a presumption rule parallel to the Akzo Nobel presumption rule has not been considered as an independent question, see for instance Van Dam, "Brothers in arms", 249, and Rott and Ulfbeck, "Supply chain liability", 429.

${ }^{68}$ It is worth noticing that in the Chandler decision, with regard to establishing reliance on the part of the employees of the subsidiary, the court stated that in assessing this element "it is not necessary to show that the parent is in the practice of intervening in the health and safety policies of the subsidiary. The court will look at the relationship between the companies more widely", Chandler v. Cape, [2012] EWCA Civ. 525, paragraph 80. Thus, although the concrete case concerned health matters, liability could be triggered by the general control exercised by the parent company over the subsidiary. The decision hereby could be seen as containing some - not clearly expressed vicarious liability elements.
} 


\subsubsection{Phase 3: Vicarious liability?}

So far, there have been only few signs, if any, that the concept of vicarious liability could be used to establish parental liability in areas of the law other than competition law. ${ }^{69}$ As explained, in the areas of competition law, the concept was first applied with regard to criminal liability. A recent legislative initiative, the French loi de vigilance ${ }^{70}$, can be mentioned as an example of the application of criminal liability to parent companies for the causing of work injuries and/or environmental damage by subsidiaries, but here liability is direct rather than vicarious.

However, a very recent decision from the UKSC might be read as a sign that the use of the concept of "the undertaking" could be under way in other areas of the law as well. Thus, in the Vedante decision ${ }^{71}$, concerning the possible liability of a British parent company for environmental damage caused by a subsidiary based in Zambia, the court used the term "a single economic undertaking", stating that at one extreme,

"the parent company may carry out thoroughoing vertical reorganisation of the groups' businesses so that they are, in management terms, carried out as if they were a single commercial undertaking, with boundaries of legal personality and ownership within the group becoming irrelevant, until the onset of insolvency, as happened within the Lehman Brothers group."

Despite the mentioning of the term "single commercial undertaking", the case concerned direct liability. ${ }^{73}$ Thus, the concept of the undertaking as used in competition law has still not been used for establishing vicarious

\footnotetext{
${ }^{69}$ For an examination of this possibility, see Vibe Ulfbeck and Andreas Ehlers "Tort law, corporate groups and supply chain liability for workers' injuries: The concept of vicarious liability", European Company Law 13, no. 5 (2016), 167.

${ }^{70}$ The French initiative makes it compulsory for companies to adopt a vigilance plan concerning activities of the company and the activities of the subsidiaries or companies it controls, see Loi no. 2017-399 du 27 mars 2017 relative au devoir de vigilance des societés mères et des entreprises donneuses d'ordre, at https://www.legifrance.gouv.fr/affichTexte.do?cidTexte=JORFTEXT000034290 626\&categorieLien=id (last accessed September 23, 2019).

${ }^{71}$ Vedanta Resources PLC and another (appellants) v. Lungowe and others (Respondents) [2019] UKSC 20.

${ }^{72}$ Vedanta Resources PLC and another (appellants) v. Lungowe and others (Respondents) [2019] UKSC 20, paragraph 51.

${ }^{73}$ The case directly only concerned procedural aspects but indirectly also expressed views on the substance matter of parental liability for the acts and omission of subsidiaries.
} 
liability in other areas of the law. This raises the question whether there are any policy reasons supporting a view that vicarious liability should only apply in competition law cases.

The concern that applying vicarious liability with regard to parent liability for subsidiaries' actions and omissions runs counter to the basic company law principle of separate units applies not only to cases concerning workers' injuries and environmental damage, but equally in the area of competition law. In both areas, there seems to be a stronger case for arguing that vicarious liability for the acts and omissions of the subsidiary would be contrary to company law principles with regard to direct liability. Thus, it could be argued that the company law doctrine of separate entities exhaustively regulates the extent to which one entity can be held liable for the acts of another entity. ${ }^{74}$ Nevertheless, these concerns have been overcome in the area of competition law. In support of overcoming the concerns also in other areas of the law, it could be pointed out that applying vicarious liability only implies imposing parental liability in situations where the subsidiary has committed a tort. Thus, it would not apply to situations concerning other types of debts on the part of the subsidiary, such as for instance a loan. Consequently, the company law doctrine of separate units would not be undermined by the use of the principle. In other words, the doctrine of separate entities in company law could be seen as leaving ample space not only for direct parental liability, but also for vicarious parental liability for torts committed by the subsidiary. The fact that this concept has for long been applied within the area of competition law could be seen as reflecting this view.

In contrast, a basic policy argument for parental liability for competition law infringements has a specific EU law angle which is not found in same direct way as in cases concerning workers' injuries and environmental liability. Thus, competition law plays a key role in the development of the common, inner market. Accordingly, market efficiency arguments are used to apply the concept of an undertaking as a "shield" and exclude the application of competition law rules on "inner group company agreements" and as a - logical - corollary to support the use of the concept of an undertaking as a "sword" to establish parental liability for competition law infringements. Outside the area of competition law, the concept of the

\footnotetext{
${ }^{74}$ This argument could be based on the fact that the rules concerning piercing of the corporate veil, just like the tort law rules on vicarious liability, concern "liability for others". Thus, it could be argued that the company law rules should be regarded as "lex specialis" in this respect.
} 
undertaking is not called for to have a "shield function" and in general market efficiency arguments can only more indirectly support parental liability for workers' injuries and environmental damage.

However, other central parts of the policy reasons for imposing parental liability for competition law infringements by subsidiaries seem to be valid also with regard to workers' injuries and environmental harm. For example, the argument that the parent company is the entity benefitting from the infringements committed by the subsidiary should also bear the economic burden generated by the infringements is of a general nature and also valid in other areas of the law. In addition, the argument that it should not be possible to evade liability by means of organisational structures seems generally applicable to all cases concerning parental liability.

In conclusion, the concerns against establishing vicarious liability apply equally in and outside the area of competition law. The fact that they have been overcome with regard to competition law infringements and that the principle within the area of competition law has now been generalised, expanding it to cover also civil liability cases, might speak in favour of also overcoming the concerns in other areas of the law, where several of the policy reasons underpinning parental liability for competition law infringements are equally applicable.

\section{Supply chain liability for competition law infringements - the application of the concept of the undertaking to companies linked by contract?}

As described above, parental liability for competition law infringements has been established even in cases where the parent company has only been a minority shareholder of the subsidiary, provided it has been possible to provide proof of a sufficient influence and control taking place in other ways. However, one might ask whether it would be possible to establish a sufficient amount of control even if the companies are not linked by ownership at all but only by contract.

Thus, over the past years, the possible liability of the lead firm ${ }^{75}$ for acts and omissions in global value chains has attracted considerable attention

\footnotetext{
${ }^{75}$ The term "lead firm" refers to the dominating company in the supply chain, often a buyer based in the global north, which is in practice dictating the terms of the contracts in the chain. In the present analysis, the chain leader in contractual chains corresponds to the parent company in owner-based structures.
} 
with regard to environmental damage and work injuries. ${ }^{76}$ Whether supply chains are based on ownership or contract is often a matter of organisational choice on the part of the lead firm. Several chains consist, in practice, of a mixture of relations based on ownership and contract, and products may be sold between parent companies and subsidiaries or between companies that are solely linked by contract. Consequently, in legal theory concerning workers' injuries and environmental damage it has been argued that the liability standard should be the same whether the supply chain is based on ownership or contract. ${ }^{77}$ Some case law with regard to workers' injuries implicitly supports this view. ${ }^{78}$ In other words, it should not be possible to circumvent liability principles by choice of organisational form. ${ }^{79}$

Following this line of thought, one might also pose the question whether a lead firm could be held liable for competition law infringements in its contractual supply chain. As an example, the possible liability of the lead firm for abuse of a dominant position by a supplier could be mentioned. Such an abuse may have been triggered by pressure put on the supplier by the lead firm to deliver goods at low prices (on the relationship between the lead firm and the supplier, see further below). The abuse may have as a consequence that the supplier's suppliers suffer losses, raising the question whether the lead firm can be held liable for these losses.$^{80}$ The policy reason for such liability would be that the lead company - at least for a period of time - gains from this abuse. ${ }^{81}$

\footnotetext{
${ }^{76}$ See in general Vibe Ulfbeck, Alexandra Andhov, Katerina Mitkidis eds., Law and Responsible Supply Chain Management (Abingdon: Routledge, 2019), with references.

${ }^{77}$ Carolijn Terwindt et al., "Supply chain liability: Pushing the boundaries of the common law", Journal of European Tort Law 8, no. 3 (2018): 261, Rott and Ulfbeck, "Supply chain liability" 415, 432.

${ }^{78}$ See Das v. George Washington Limited [2018] ONSC 1053.

${ }^{79}$ It was the exact same reasoning that was put forward in Judgment of 14 March 2019, Vantaan Kaupunki v. Skanska Industrial Solutions Oy, NCC Industry Oy, Asfaltmix Oy, C-724/17, EU:C:2019:204, paragraph 46, see further above.

${ }^{80}$ The CJEU has previously dealt with similar situations with regard to company groups. As an example, the merger case Europemballage and Continental Can v. Commission (Judgment of 21 February 1973, Europemballage Corporation and Continental Can Company Inc. v. Commission of the European Communities, C-6/72, [1973] ECR 2015 could be mentioned. In this case a New York corporation was found to have acquired a dominant position in the EEC through the action (a take-over bid) of a European subsidiary. The parent company and the subsidiary were considered to be one economic unit with the consequence that the Commission had jurisdiction over the case, see paras 15-17.

${ }^{81}$ It may be argued that in the long run, the lead company will not gain but lose if a supplier abuses a dominant position since this will make prices go up. A more precise estimation of the effects in the chain would require an economic analysis of the mechanisms in the specific chain.
} 
With regard to liability for competition law infringements in supply chains based on contract, the central question is whether two companies tied together by contract can constitute an "undertaking" as this concept is understood in competition law. As described above, the central criterion in case law seems to be the amount of control exercised by the lead firm on the supplier.

Supply chain structures vary considerably and, consequently, so does the amount of control exercised by the lead company on its suppliers. However, also in supply chains based on contract, the lead firm will often have a large amount of control with the chain. As put by Faull and Nikpay: "The whole nature of distribution has been changed by the information technology revolution and the adoption of just-in-time (JIT) principles" ${ }^{82}$ Thus, a small supplier may in reality have market access only through a particular lead company and the lead company may in reality set the terms of the contract and have the right to vary these terms unilaterally during the contractual period of time..$^{83}$ The relationships are often long term and the lead firm may monitor the supply chain and its performance. ${ }^{84}$ One of the reasons for the exercise of control over the supply chain is the societal demand that lead firms secure sustainability in their supply chains. This demand is reflected in legislative requirements to report on CSR policies ${ }^{85}$ and to exercise "due diligence" with regard to sustainability efforts in the supply chain. "Supply chain management" has become a recognised discipline and is concerned not only with the flow of goods but increasingly also with services, finances, information and marketing. ${ }^{86}$ Companies use tools such as company policies, joint management committees, open book accounts, monitoring, certification and internal supply chain dispute

\footnotetext{
${ }^{82}$ Jonathan Faull and Ali Nikpay, eds., The EC Law of Competition, $2^{\text {nd }}$ edition (Oxford: Oxford University Press: 2007), 1183, mentioning also that "the absence of risk relating to individual transaction, which was the main criterion used for differentiating an agent from an independent trader, is no longer the preserve of the commercial agent". As an example of a case applying the classical distinction between agents and independent traders, see Confederación Española de Empresarios de Estaciones de Servicio v. Compañia Española de Petróleos SA., C-217/05.

${ }^{83}$ Vibe Ulfbeck and Ole Hansen, "Interplay between contract and tort in the supply chain", in Responsible Supply Chain Management, eds. Vibe Ulfbeck, Alexandra Andhov, Katerina Mitkidis (Abingdon: Routledge 2019), 140.

${ }^{84}$ Ulfbeck and Hansen, "Interplay", 140, with further references.

${ }^{85}$ Directive 2014/95/EU, 'Non-Financial Information Directive'.

${ }^{86}$ John T. Mentzer, et al., "Defining supply chain management", Journal of Business Logistics 22, no. 2 (2001): 4 .
} 
resolution mechanisms to exercise supply chain management. ${ }^{87}$ Depending on the degree of management on the part of the lead firm, a supply chain may in many ways be seen as functioning as a whole rather than as a number of different entities connected by ownership or contract. ${ }^{88}$

Thus, although supply chains differ, it would be perfectly possible to identify chains in which - although based on contract - the supplier does not function independently but simply "carries out the instructions of the buyer" as expressed in the Imperial Chemical case described above. ${ }^{89}$

Likewise, many of the tools for control mentioned in the Dow case are also used in supply chains based on contract, such as joint member committees with management power over the suppliers, ${ }^{90}$ the ability to carry out supervision of the supplier ${ }^{91}$ and to police compliance ${ }^{92}$ with the policies of the lead company. This all speaks in favour of regarding it as a possibility that companies tied by contract could indeed be regarded as an "undertaking" with regard to competition law infringements with the consequence that the lead company could be held liable for the infringements committed by its contractual supplier, even if it had no knowledge of these infringements taking place.

The flipside of the coin would be that agreements between the lead firm and the supplier would then need to be regarded as "internal" agreements in the supply chain, not subject to article 101 and 102 of the Treaty. ${ }^{93}$ That

\footnotetext{
${ }^{87}$ Ulfbeck and Hansen, "Interplay", 140, with references, Vibe Ulfbeck Alexandra Andhov, Katerina Mitikidis, "Introduction", in Responsible Supply Chain Management, eds. Vibe Ulfbeck Alexandra Andhov, Katerina Mitikidis (Abingdon: Routledge 2019), 5-6. On certification in supply chains, see Carola Glinski and Peter Rott, "The role and liability of certification organisations in transnational value chains", Deakan Law Review 23 (2018): 83.

${ }^{88}$ Ulfbeck, Andhov, Mitikidis, "Introduction", 5-6, Ole Hansen, Vibe Ulfbeck, Clement Salung Petersen, "Private governance and the potential of private law" (forthcoming in The European Review of Private Law, 2019).

${ }^{89}$ Judgment of 2 February 2012, Dow Chemical v. European Commission, T-77/08, EU:T:2012:47, paragraph 133. In supply chain literature, the term "captive supply chains" is sometimes used to express this reality, see G. Gereffi, J. Humphrey, T. Sturgeon, "The governance of global value chains", Review of International Political Economy (RIPE) 12, no. 1 (2005): 78-79.

${ }^{90}$ Judgment of 2 February 2012, Dow Chemical v. European Commission, T-77/08, EU:T:2012:47, paragraph 87.

${ }^{91}$ Judgment of 2 February 2012, Dow Chemical v. European Commission, T-77/08, EU:T:2012:47, paragraph 101.

${ }^{92}$ Judgment of 2 February 2012, Dow Chemical v. European Commission, T-77/08, EU:T:2012:47, paragraph 101.

${ }_{93}$ On the discussion concerning a related topic, namely the compliance with EU competition law of horizontal sustainability agreements by parties in a supply chain, see Giorgio Monti and Jotte
} 
this could in fact be the case is supported by the fact that in the view of the Commission, even some vertical agreements that imply transfer of knowhow from the contractor to the supplier should be regarded as not infringing article 101(1) of the Treaty. ${ }^{94}$ Moreover, to the extent that technology or equipment transferred from the contractor to the supplier is necessary to enable the subcontractor to fulfil its contractual obligations towards the contractor, "the subcontractor is not regarded as an independent supplier in the market". ${ }^{95}$ If the supplier is not regarded as an independent supplier in the market for the purpose of art 101(1), it seems reasonable to ask if the corollary of this lack of independence from the contractor (the lead firm) could be vicarious liability of the lead firm for competition law infringements committed by the supplier.

\section{Conclusion}

On the basis of the above, it can be concluded that parent companies may incur vicarious liability for competition law infringements caused by the acts and omissions of their subsidiaries, if the parent company and subsidiary must be regarded as an economic unit. Following the Skanska decision, it must be presumed that this applies whether the liability incurred by the subsidiary is administrative liability or civil liability. Thus, a more general principle of vicarious liability on the part of parent companies for competition law infringements by the subsidiaries seems to have been established. Other areas of the law seem less developed in this regard. Thus, with regard to liability for workers, injuries and environmental harm, the general rules still seems to be fault-based liability. Vicarious liability has not been introduced in case law. One of the reasons for this may be that market efficiency arguments are particularly forceful within the area of competition law and can be seen as partly underpinning the law with regard to parental liability for competition law infringements committed by subsidiaries. However, several of the other policy reasons which lie behind the expansion of parental liability in competition law apply equally in other areas of the law. Most obviously, this is true with regard to the argument that it should not be possible for a parent company to gain from

\footnotetext{
Mulder, "Escaping the clutches of EU Competition Law - Pathways to assess private sustainability initiatives", European Law Review 42, no. 5 (2017).

${ }^{94}$ See Richard Wish and David Bailey, Competition Law, $9^{\text {th }}$ edition (Oxford: Oxford University Press, 2018), 621 with reference to the Commission's "Vertical guidelines".

${ }^{95}$ Wish and Bailey, Competition Law, 622.
} 
infringements of the law committed by a subsidiary without being held accountable. This speaks in favour of introducing the concept of vicarious liability for parent companies in other areas of the law as well. In addition, it could be argued that both in the area of competition law and in other areas of the law, the concept of an undertaking could be applicable not only with regard to groups of companies but, under certain conditions, also when companies are linked by contract, since it should not be possible to evade liability simply by choice of organisational form.

\section{Bibliography:}

Bronckers, Marco and Anne Vallery. "No longer presumed guilty? The impact of fundamental rights on certain dogmas of EU Competition Law". World Competition 34, no. 4 (2011): 535-570.

Cortese, Bernardo. "Piercing the corporate veil in EU Competition Law: The parent subsidiary relationship and antitrust liability". In EU Competition Law - Between Public and Private Enforcement", edited by Bernardo Cortese, 73-93. Alphen aan den Rijn: Kluwer Law International, 2014Kluwer, 2014.

Enneking, Liesbeth. Foreign Direct Liability and Beyond. Exploring the Role of Tort Law in Promoting International Corporate Social Responsibility and Accountability. The Hague: Eleven International Publishing, 2012.

Faull, Jonathan and Ali Nikpay (eds.). The EC Law of Competition, $2^{\text {nd }}$ edition. Oxford: Oxford University Press, 2007.

Glinski, Carola and Peter Rott. "The role and liability of certification organisations in transnational value chains”. Deakan Law Review 23 (2018): 83-117.

Islentyeva, Ekaterina. "Like father, like son - The parental liability under the EU Competition law today”. Global Antitrust Review (2011): 99-115.

Kalintiri, Andriani. "Revisiting parental liability in EU competition law". European Law Review 43, no. 2 (2018): 1-22.

Monti, Georgio and J. Mulder. "Escaping the clutches of EU Competition Law Pathways to assess private sustainability initiatives”. European Law Review 42, no. 5 (2017): 635-656.

Rott, Peter and Vibe Ulfbeck. "Supply chain liability of multinational corporations". European Review of Private Law 23, no. 3 (2015): 415-436.

Spier, Jaap (ed.). Unification of Tort Law: Liability for Damage Caused by Others. Alphen aan den Rijn: Kluwer Law International, 2003.

Terwindt, Carolijn, Sheldon Leader, Anil Yilmaz-Vastardis and Jane Wright. "Supply chain liability: Pushing the boundaries of the common law". Journal of European Tort Law 8, no. (3) (2018): 261-296. 
Ulfbeck, Vibe, Alexandra Andhov and Katerina Mitkidis (eds.). Law and Responsible Supply Chain Management. Abingdon: Routledge, 2019.

Ulfbeck, Vibe and Andreas Ehlers. "Direct and vicarious liability in supply chains". In Law and Responsible Supply Chain Management, edited by Vibe Ulfbeck, Alexandra Andhov and Katerina Mitkidis, 91-110. Abingdon: Routledge, 2019.

Ulfbeck, Vibe and Andreas Ehlers. "Tort law, corporate groups and supply chain liability for workers' injuries: The concept of vicarious liability”. European Company Law 13, no. 5 (2016): 167-174.

Ulfbeck, Vibe and Ole Hansen. "Interplay between contract and tort in the supply chain". In Responsible Supply Chain Management, edited by Vibe Ulfbeck, Alexandra Andhov and Katerina Mitkidis, 133-146. Abingdon: Routledge, 2019.

Van Dam, Cees. "Tort law and human rights: Brothers in arms - On the role of tort law in the area of business and human rights". Journal of European Tort Law 2, no. 3 (2011): 221-254.

Wils, Wouter P. J. “Antitrust compliance programmes and optimal antitrust enforcement”. Journal of Antitrust Enforcement 1, no. 1 (2013): 52-81.

Wish, Richard and David Bailey. Competition Law, $9^{\text {th }}$ edition. Oxford: Oxford University Press, 2018. 